\title{
Solid Waste Management in Owerri Municipality and its Immediate Environs
}

\author{
Felicia E. Uwakwe
}

Department of Biotechnology

Federal University of Technology

Owerri-Nigeria

Doi:10.5901/ajis.2012.v2n5p141

Abstract

In recent years, there has been a tremendous increase in solid waste generation, resulting to the heaps of refuse along major streets and roads in most cities of Nigeria, and other developing countries. The need to control this ugly situation and make our environment pristine, healthy and supportive prompted this work. The study involved gathering of field information to reveal the major types and sources of solid wastes, their modes of management and the environmental and health implications. To direct the study, two research questions and one hypothesis were formulated. The instrument used was a questionnaire which was administered to 836 respondents selected from 8 streets in Owerri Municipality and 2 satellite communities (Amakohia and Orji in Owerri North LGA). The findings showed the major components of solid waste generated to be biodegradable (62\%) with the major source being markets (44\%), while the predominant management method was open dumping system (46\%). Majority of the respondents $(88.4 \%)$ indicated awareness of the adverse health and environmental impacts of improper solid waste management. Generally, the waste management methods adopted were found to be ineffective and an integrated waste management system is therefore advocated.

\section{Introduction}

Generally, wastes are materials or substances which are regarded as useless by the producers or holders and therefore disposed of. Wastes occur in three different forms; solid, liquid and gaseous. The World Health Organization (WHO, 1994) defined solid waste as an unwanted and discarded material resulting from domestic, community, industrial commercial and agricultural operations with insufficient liquid content to be free flowing.

Waste generation is an on-going process and occurs in all places where life abounds. As an integral part of metabolism, living organisms produce different types of waste products which are released into the environment. Aside this, other activities of man such as agriculture, food processing, wood work, building and construction and others also release various forms of wastes into the environment. In the past, the wastes produced were mainly organic and sufficiently decayed by saprophytic microbes and therefore posed no harm to the quality of the environment and human health.

The era of technological advancement and industrialization has introduced various forms of equipment and facilities into government offices, residential homes, institutions, industries and commercial centres. The application of these gadgets has tremendously improved production and living standard of the people and consequently the economy of many countries. However, the introduction and use of these machines result in generation of more wastes, some of which are non-biodegradable and hazardous. Also the quantity and quality of organic wastes produced have become enormous and gone beyond the natural cleansing limit of microbes, resulting to the heaps of refuse found along the streets, roads, gutters, markets places and even in rivers in most cities of developing countries. Furthermore, urbanization brings about increased population in urban cities. Commenting on the alarming rate of urban population growth, Imam, et al (2007) reported that while Nigeria's population increased by about $2.8 \%$ per annum, the rate of urban growth is as high as $5.5 \%$ 
per annum. Increase in population means increase in waste generation which pollute the environment and causes health hazards.

The problem of solid waste disposal has become one of the most serious problems facing many cities of the world more especially developing countries. Management of solid waste according to Buckle and Smith (2000) encompasses all the activities that seek to minimize the health, environmental and aesthetic impacts of solid wastes. Many urban cities lack effective solid waste management systems and consequently the major part of generated wastes is indiscriminately released into the environment. Accumulation of solid waste creates health problems which include pollution, global warming and climate change due to release of green house gases, increased disease incidence such as malaria, cholera, diarrhea, dysentery, respiratory tract infection and other filth -related diseases (Environment Canada, 2002, Nwankwo, 2008). Other problems associated with waste accumulation are blockage of roads and drainage systems, flooding, accidents and environmental degradation.

In this era of climate change which is associated with ozone layer depletion and global warming, proper solid waste management becomes necessary to reduce the emission of greenhouse gasses, hazardous radiations, chemicals and gases. Achieving effective solid waste management has been identified by Karl Burkart (2010) as one of the six activity sectors essential for the meaningful operation of green economy. The target of green economy according to Iwuala (2012) is sustainable development in a sanitary, healthy and supportive environment. Furthermore, parts of the Millennium Development Goals (MDGs) include combating HIV/AIDs, Malaria and other diseases as well as ensuring environmental sustainability. These goals can only be achieved through effective solid waste management which is a planned system of effectively controlling the production, storage, collection, transportation, processing and disposal or utilization of wastes in a sanitary, aesthetically acceptable and economic manner. Effective solid waste management therefore keeps the environment free from harm, pollution, noise, odour, poisonous gases, fumes and other harmful substances (Nwankwo, 2008). This in turn promotes the operation of green economy which leads to sustainable development.

\section{Methodology}

Study Area

The study area comprised Owerri Municipal and its immediate environs, Amakohia and Orji, both in Owerri North Local Government Council Area. Owerri is the capital of Imo State in South-Eastern Nigeria. Amakohia and Orji are satellite communities having no clearly defined demarcations from Owerri Municiaplity. The study area is densely populated and houses many institutions of learning, churches, hospitals and clinic, markets and other commercial centres. All these establishments, plus the various homes and other business outfits constitutes sources of solid waste generation.

\section{Research design}

The research design adopted was analytical survey. The reason being that the method compares measurable variables between groups and is favoured in testing hypothesis. The detailed methodology included questionnaire administration, formal and informal interviews, field trips and direct observations.

Research questions and hypothesis

In order to achieve the objectives of the study, the following research questions and hypothesis were addressed. 
- What are the major types and sources of solid waste generated in Owerri Municipality and its immediate environs?

- What are the waste management methods available in the study area for handling the enormous wastes generated daily?

- $\mathbf{H}_{0}$ : Improper solid waste management has no significant impact on the environment and health conditions of the people.

Study Population and sampling techniques

The study population comprised adults in the study area who are conversant with the concept of waste generation and disposal. A stratified sampling method was employed using a sampling frame consisting of the names of the streets in Owerri Municipality obtained from the evaluation unit of the council. The list comprising 80 streets written serially was divided into eight groups labeled A-H, with group a consisting of Nos. 1-10, B, 11-20 and so on. Simple random sampling was used to select one street from each group, giving a total of 8 streets, plus the 2 satellite communities. 100 respondents were considered from each street, giving a sample of 1000 .

Procedure for data collection

An open and close ended questionnaire was constructed, validated and administered to the selected study sample. The questionnaire was administered on a face to face bases. Out of 1000 copies administered, 929 copies were retrieved. During assessment, it was discovered that 42 were incompletely filled and 51 not filled at all, while 836 were completely filled and used for analysis. Several efforts to retrieve the remaining copies proved abortive. Administration and collection of instrument last 9 weeks.

Data analysis

The data obtained from questionnaire was analyzed using simple percentages and chi-square tests. These statistical methods were used because they give clear deviations between observed and expected values in order to provide a test of significance which is important in decision making.

\section{Result and Discussion}

Table 1: Personal data of questionnaire respondents $(n=836)$

\begin{tabular}{|l|c|c|}
\hline \multicolumn{1}{|c|}{ Variables } & No. of Respondents & Percentages of $\mathbf{~ n}$ \\
\hline Age & & $25.4 \%$ \\
\hline $20-29$ & 212 & $15.8 \%$ \\
\hline $30-39$ & 132 & $44.5 \%$ \\
\hline $40-49$ & 372 & $13.2 \%$ \\
\hline 50 and above & 111 & $1.1 \%$ \\
\hline No. response & 9 & \\
\hline Sex & & $46.8 \%$ \\
\hline Male & 391 & 53.2 \\
\hline Female & 445 & \\
\hline Marital status & & $47.1 \%$ \\
\hline Single & 394 & \\
\hline
\end{tabular}




\begin{tabular}{|l|c|c|}
\hline Married & 426 & $50.0 \%$ \\
\hline No response & 16 & $11.9 \%$ \\
\hline Educational qualification & & $3 \%$ \\
\hline FSLC & 25 & $34.9 \%$ \\
\hline WASC/GCE & 292 & $51.7 \%$ \\
\hline OND/HND/B.ED/B.SC & 432 & $6 \%$ \\
\hline M.Sc/Ph.D & 50 & $4.4 \%$ \\
\hline No response & 37 & \\
\hline Occupation & & $43.8 \%$ \\
\hline Civil/Public servant & 366 & $17.5 \%$ \\
\hline Self-employed & 147 & $10.2 \%$ \\
\hline Private sector & 85 & $25.5 \%$ \\
\hline Student & 213 & $3 \%$ \\
\hline No response & 25 & \\
\hline
\end{tabular}

$\mathrm{n}=$ Sample size

Results obtained from the respondent personal data presented the study area as a literate community (OND/HND/B.Ed/B.SC, 51.7\%), with majority of the populace being civil servants (43.8\%), married folks $(50 \%)$ and falling between the age bracket of 40-49 (44.5\%). The findings showed that residents of Owerri Municipality and its environs are conversant with the concept of waste generation and management. This places them in a better position to participate fully in effective solid waste management programs, as well as help others especially the under aged to imbibed the ethics.

Table 2: Major Types and sources of solid wastes

\begin{tabular}{|l|c|c|}
\hline Variables & No. of Respondents & Percentages of n \\
\hline Waste types & & \\
\hline Biodegradation & 520 & $62.2 \%$ \\
\hline Non-Biodegradable & 264 & $31.6 \%$ \\
\hline No response & 52 & $6.2 \%$ \\
\hline Sources of wastes & 160 & \\
\hline Residential homes & 368 & $49.1 \%$ \\
\hline Markets & 20 & $2.4 \%$ \\
\hline Academic institutions & 38 & $4.5 \%$ \\
\hline Hospitals & 61 & $7.3 \%$ \\
\hline Business out fits (banks, hotels etc) & 180 & $21.5 \%$ \\
\hline Two or more options & 9 & $1.1 \%$ \\
\hline No response & & \\
\hline
\end{tabular}

Assessment of the types of waste generated showed that the major component was biodegradable $(62 \%)$ s while non biodegradation accounted for $31.6 \%$ of generated wastes. The finding agrees with earlier work by oil resources and Allied Investment Limited (2008) which gave the figures of biodegradable and nonbiodegradable wastes as $54 \%$ and $46 \%$. The finding is also consistent with the results obtained from waste types generated in selected African cities as compiled by Asomani-Boateng and Haight (2008) which gave the percentage organic wastes as thus: Kumas $83 \%$, Accra $85 \%$, Ibadan $55.8 \%$, Kampala $75 \%$ and Kigali $94 \%$. Owerri is an administrative city and residents are mostly civil /public servants $(43.8 \%$ and students $25 \%$ ). The economic and social status of the city could be the main reason for the huge amount of biodegradable wastes generated. 
Investigation into the major sources of solid waste generation presented markets as the major source. This finding differed from the view of Obere, UN (Personal Interview) of the ministry of petroleum and environment who regarded residential homes as the major source. It is certain that markets are centres of commercial activities in any city and accommodate greater number of people than any other sector at any given time. The increased human population and activities in markets could account for the huge quantities of different kinds of wastes around the markets in the municipality and its environs.

Table 3: Available waste management methods

\begin{tabular}{|l|c|c|}
\hline \multicolumn{1}{|c|}{ Variables } & No. of Respondents & Percentages of n \\
\hline Sanitary land fill & 126 & $15.1 \%$ \\
\hline Burning & 113 & $13.5 \%$ \\
\hline Open dumping & 385 & $46 \%$ \\
\hline Ocean dumping & 7 & $0.8 \%$ \\
\hline Composting & 18 & $2.2 \%$ \\
\hline Recycling & 13 & $1.6 \%$ \\
\hline Waste separation & 19 & $2.3 \%$ \\
\hline Two or more options & 149 & $17.8 \%$ \\
\hline No response & 6 & $0.7 \%$ \\
\hline
\end{tabular}

On the waste management method practiced, it was found that open dumping (46\%) which is the least acceptable method superseded the others while sanitary landfill $(15.1 \%)$ and burning (13.5\%) ranked $2^{\text {nd }}$ and $3^{\text {rd }}$ respectively. These finding agree with those of Olafusi (2004) and Iman et al (2007) who reported that in most cities of Nigeria and other developing countries, the greater percentages of generated are dumped on the surface of the ground along major roads, streets and open spaces. The finding was further confirmed by the information obtained from field trips and direct observations which revealed the existence of more than 250 dumpsites of different sizes within the municipality and its environs. The reasons for adopting open dumping as the main waste management method could be unavailability of adequate man-power and equipment, inaccessibility to final dumpsites, people's poor attitude towards environmental sanitation as well as the method being cheap but not cost effective. It was discovered that the quality of wastes generated daily has over-whelmed the existing man-power and equipment resulting to their constant break down. This ascertion was confirmed by the information obtained from the Bureau of Sanitation and Transport Unit, ENTRACO which gave the number of existing equipment as thus: Ford Tractor I (Not functional), NDDC Trucks 20 (8 Functional, 12 not), Axon Mercedes tippers 3 (all functional), Waste Bins, newly procured 30, old bins 120 and damaged ones 60 . The reason for lack of adequate equipment and trained man-power may be ascribe to lack of funds, corruption, poor maintenance culture and lack of executive will whereby investment in waste management is regarded as a waste of resources since it is regarded as a non- profitable venture.

Other waste management methods identified were either purported or practiced at a minimal level and could not contribute meaningfully to effective solid waste management. Giving credence to these findings people directly involved in waste handling confirmed that there is no concrete solid waste management system, describing the method practicsed as simply refuse displacement which involves the transfer of wastes from one location to another.

Table 4: Health and environmental impacts of solid wastes 


\begin{tabular}{|c|c|c|}
\hline Variables & No. of Respondents & Percentages of $n$ \\
\hline \multicolumn{3}{|c|}{ Whether waste management system is effective } \\
\hline Yes & 184 & $22.0 \%$ \\
\hline No & 652 & $78.0 \%$ \\
\hline \multicolumn{3}{|c|}{ Whether people are ware of the impacts } \\
\hline Yes & 739 & $88.4 \%$ \\
\hline No & 97 & $11.6 \%$ \\
\hline \multicolumn{3}{|c|}{ Observed features at waste dumpsites } \\
\hline Burning /smoke & 138 & $16.5 \%$ \\
\hline Flies and mosquitoes & 143 & $17.1 \%$ \\
\hline Odour emission & 249 & $29.8 \%$ \\
\hline Rats and other animals & 12 & $1.4 \%$ \\
\hline Waste pickers/scavengers & 23 & $2.8 \%$ \\
\hline Two or more options & 259 & $31 \%$ \\
\hline No response & 6 & $0.7 \%$ \\
\hline \multicolumn{3}{|l|}{ Some observed impacts } \\
\hline Pollution & 180 & $21.5 \%$ \\
\hline Flooding & 43 & $5.1 \%$ \\
\hline Disease vectors/disease out-break & 174 & $20.8 \%$ \\
\hline Fire out-break & 24 & $2.9 \%$ \\
\hline Road blockage & 46 & $5.5 \%$ \\
\hline Accidents & 4 & $0.5 \%$ \\
\hline Environmental degradation & 47 & $5.6 \%$ \\
\hline Two or more options & 302 & $36.1 \%$ \\
\hline No response & 16 & $2 \%$ \\
\hline
\end{tabular}

Table 5: Chi-squared analysis of hypothesis 1

\begin{tabular}{|c|c|c|c|c|c|}
\hline \multirow[b]{2}{*}{ Variables } & \multicolumn{2}{|c|}{ YES } & \multicolumn{2}{|c|}{ NO } & \multirow[b]{2}{*}{ Total } \\
\hline & Observed & Expected & Observed & Expected & \\
\hline $\begin{array}{l}\text { Whether waste management system } \\
\text { is effective }\end{array}$ & 184 & $\begin{array}{c}461.5 \\
(-277.5) \\
\end{array}$ & 652 & $\begin{array}{c}374.5 \\
(277.5)\end{array}$ & 836 \\
\hline $\begin{array}{l}\text { People's knowledge of the health } \\
\text { impacts of waste dumpsites. }\end{array}$ & 739 & $\begin{array}{c}461.5 \\
(-277.5)\end{array}$ & 97 & $\begin{array}{c}374.5 \\
(277.5)\end{array}$ & 836 \\
\hline Total & 923 & & 749 & & 1672 \\
\hline
\end{tabular}

Using the formular $\mathrm{X}^{2}=\left(\underline{\mathrm{O}-\mathrm{E})^{2}}\right.$

$$
\mathrm{E}
$$

Where $\mathrm{X}^{2}=$ Chi-squared, $\mathrm{O}=$ observed figure and $\mathrm{E}=$ expected value. The bracketed figures represents the differences between observed and expected values.

$$
\mathrm{X}^{2}=744.96
$$

Critical Value $=3.84(\mathrm{dfn}=1, \mathrm{P}=0.05)$

$\mathrm{X}^{2}>$ critical value

$\mathrm{H}_{0}$ is rejected

The hypothesis was formulated to determine the relationship between improper solid waste management and public health. From the analysis, $X^{2}$ calculated $(744.96)$ is very much greater than the critical value (3.84), depicting a high level of significance and rejecting the null hypothesis $\left(\mathrm{H}_{0}\right)$. This implies 
that improper solid waste management poses a great threat to the health conditions of the people, and the environment. This results is consistent with the work carried out by Yhdego and Majura (1988), Stephen and Harpham (1992), and Songsore and macGranahan (1993) who attributed the prevalence of diseases, morbidity and mortality in Most African cities to poor sanitation and improper waste disposal practices. The finding was further corroborated by the reports of environment Canada (2002), Olotuah and Fadairo (2005) and USAID (2008) which disclosed that flooding, climate change and environmental degradation were partly due to the effects of improper solid waste management systems in developing countries.

From the results obtained, most people claimed being aware $(88.4 \%)$ of the health and environmental impacts of improper solid waste disposal, yet wastes are dumped indiscriminately in and around the city. The unsanitary health conditions could therefore not only be attributed to inadequate supply of equipment and man-power or lack of awareness but to people's poor attitude to waste disposal and environmental hygiene, and lack of legislation which depicts in the manner people throw out wastes from moving vehicles, litter homes, institutions, markets and business premises with wastes, misuse public lavatories and defecate on roadsides even in broad day light. It is a common practice now especially around the municipality for landlords not to install toilet facilities in their houses, leaving their tenants with the options of either using nearby bushes or polythene bags which are thrown out along with other wastes, while wastes water is channeled to the roads.

The objective of environmental sanitation is to create and maintain conditions that will promote health and prevent diseases (Lucas and Gilles, 1990). Diseases associated with unsanitary health conditions include cholera, dysentery, diarrhea, gastroenteritis, malaria, typhoid fever and various other air- and water-related diseases (USAID, 2008, Waste Info Sheet, 2009). These disease if mishandled can lead to morbidity and death. Consequently, with decayed environment and loss of man-power, the people are unable to maximize benefits of developing the environment and exploiting the available resources to service the essential needs of the populace. This in turn affects the economic development of the city and achievement of sustainable development.

\section{Conclusion}

In owerri municipality and its environs, the main component of generated waste is biodegradable and the major source is market. The concept of solid waste management is not properly addressed, hence the adoption of open dumping as the predominant method of waste management. The consequences include pollution, disease out-break, and environmental hazards like flooding, road blockage, accidents, fire outbreaks and aesthetic degradation. This shows that there is a cause and effect relationship between proper solid waste management and people's health conditions and economic growth. It is when solid wastes are efficiently handled, that the environment becomes pristine, friendly and protected from diseases. This calls for a synergy between government, private sector, groups, individuals and the media

\section{Recommendations}

Considering the environmental and health implications of improper solid waste management, the following recommendation are made:

1. That an integrated waste management system which embraces waste separation, recycling, composting, sanitary landfill and incineration be adopted.

2. That government should make adequate budgetary provision for the procurement and installation of modern equipment and facilities, training and employment of professionals in waste handling.

3. That sanitation laws be enacted and enforced on all citizenry. 
4. That waste management issues be separated from other sections and handled by technically-biased personnel to avoid overlap of functions which leads to inefficiency.

\section{References}

Asomani-Boaleng, R. and Haight, M. (2008) Reusing organic solid waste in urban farming in African Cities: a challenge for Urban planners. Documents II (15) pp. 1-14.

Buckle and Smith (2000) Solid Waste handling in Metropolitan. Washington D.C. United States public Health Service (USPHS) publication.

Burkart, K. (2010) How do you define the green economy? http://www.mnn.com/greentech/researchinnovations/blog.

Environment Canada (2002) Curbing the Effects of Waste on Climate. http://www.ec.gc.ca/science/sandenovoz/article1_e.htm

Imam, A. Mohammed, B. Wilson, D.C and Cheeseman, C. R (2007) Solid waste management in Abuja. Doi:10.1016/j.wasman. 2007.01.006.

Iwuala, M.O. E. (2012) Green Economy: The Practical Implications. In proceedings of 2012 World Environment Day. Owerri, Imo State Nigeria.

Lucas, A.O. and Gilles, H.M. (1990) A Short textbook of Preventive Medicine for the Tropics. Ibadan: Nigeria. Bounty press Limited

Nwankwo, B.O. (2008) Solid Waste Generation and Management among Traders in Owerri Municipal Markets, Imo State. The Journal of environmental Health (JEH) Vol. 5, No.2 pp. 56-63.

Oil Resources and Allied Limited (2008). The study of Solid Waste Generation and Management in Owerri Metropolitan City. A consultancy service agreement report presented to the Ministry of petroleum and Environment. Owerri: August 13, 2008.

Olafusi, O.R (2004) Waste Disposal and Management. A case for healthy environment. Unpublished Housing Seminar Report, Department of Architecture, federal University of technology, Akure, Nigeria.

Olotuah, A.O. and Fadairo, G (2005) Flooding and the Urban Environment. Journal of Applied Sciences. 8 (1) pp. 4511 4518 .

Songsore, J and Mc Granahan, G. (1993) Environment, Wealth and Health: Towards an Analysis of Intra-Urban Differential within the Greater Accra Metropolitan Area, Accra, Ghana. Sweden. Stochholm environmental institute.

Stephen, C and Harpham, T (1992) Health and Environment in Urban Areas in Developing Countries. Third world planning review. 14 (3)

USAID (2008) Urban Sanitation and Waste Water Treatment: Making Cities work. ttp:/www.makingcitieswork.org/urban themes/ environment/sanitation.

Waste Info sheet (2009) Waste Disposal Methods: Advantages and disadvantages file://D:assign/wastedisposalmethod.htm

Yhdego, M and Majura, P. (1998) Malaria control in Tanzania. Environmental International. 14pp. 479-483. 